INTERNATIONAL

FOOD POLICY

RESEARCH

INSTITUTE

IFPRI

IFPRI Discussion Paper 01894

December 2019

\title{
Gender and Assets in Rural Myanmar \\ A Cautionary Tale for the Analyst
}

\author{
Isabel Lambrecht
}

Kristi Mahrt

Development Strategy and Governance Division

Environment and Production Technology Division 


\section{INTERNATIONAL FOOD POLICY RESEARCH INSTITUTE}

The International Food Policy Research Institute (IFPRI), established in 1975, provides research-based policy solutions to sustainably reduce poverty and end hunger and malnutrition. IFPRI's strategic research aims to foster a climate-resilient and sustainable food supply; promote healthy diets and nutrition for all; build inclusive and efficient markets, trade systems, and food industries; transform agricultural and rural economies; and strengthen institutions and governance. Gender is integrated in all the Institute's work. Partnerships, communications, capacity strengthening, and data and knowledge management are essential components to translate IFPRI's research from action to impact. The Institute's regional and country programs play a critical role in responding to demand for food policy research and in delivering holistic support for country-led development. IFPRI collaborates with partners around the world.

\section{AUTHORS}

Isabel Lambrecht (i.lambrecht@cgiar.org) is a research fellow in the Development Strategy and Governance Division of the International Food Policy Research Institute (IFPRI), Yangon, Myanmar.

Kristi Mahrt (k.mahrt@cgiar.org) is a senior research analyst in the Environment and Production Technology Division and the Development Strategy and Governance Division of IFPRI, Fort Collins, USA.

\footnotetext{
Notices

${ }^{1}$ IFPRI Discussion Papers contain preliminary material and research results and are circulated in order to stimulate discussion and critical comment. They have not been subject to a formal external review via IFPRI's Publications Review Committee. Any opinions stated herein are those of the author(s) and are not necessarily representative of or endorsed by IFPRI.

${ }^{2}$ The boundaries and names shown and the designations used on the map(s) herein do not imply official endorsement or acceptance by the International Food Policy Research Institute (IFPRI) or its partners and contributors.

${ }^{3}$ Copyright remains with the authors. The authors are free to proceed, without further IFPRI permission, to publish this paper, or any revised version of it, in outlets such as journals, books, and other publications.
} 


\begin{abstract}
This paper uses evidence from Southeast Asia to challenge current interpretations of quantitative data on individual, formal asset ownership in relation to women's decision-making power and empowerment. By overlaying quantitative data with a qualitative understanding of gender norms in rural households in Myanmar, we challenge common interpretations that have been assumed to universally reflect women's empowerment. The paper warns that measures of individual asset ownership and decision-making may be poor indicators of women's empowerment in Southeast Asia, and that a proper understanding of context is required for appropriate and meaningful interpretation of what have now become standard indicators.
\end{abstract}




\section{Acknowledgements}

This work was undertaken as part of the CGIAR Research Program on Policies, Institutions, and Markets (PIM) led by the International Food Policy Research Institute (IFPRI). Funding support for this study was provided by PIM, the United States Agency for International Development (USAID), and the Livelihoods and Food Security Fund (LIFT). We thank these donors for their kind contributions to improving the livelihoods and food security of rural people in Myanmar. This paper has not gone through IFPRI's standard peer-review procedure. The opinions expressed here belong to the authors, and do not necessarily reflect those of PIM, IFPRI, CGIAR, USAID or LIFT.

The authors of this report would like to express their sincere gratitude to all respondents who participated in this research, as well as to the village leaders or their representatives who supported and facilitated this effort. We also acknowledge excellent research assistance and input from Khin Zin Win, Hnin Ei Win, and Nang Lun Kham Synt. Finally, we thank Duncan Boughton for his feedback. 


\section{Introduction}

The individual has become a prominent unit of analysis in the intra-household and gender literature. Previously, analysts and policymakers measured and analyzed what the household owned, earned, and spent. Gradually, by recognizing the diversity of individuals within a household, grew the recognition that welfare may not be equally distributed among household members. When resources are limited, households need to decide how they will be distributed. Cognizant of observed gender inequalities and intrahousehold inequality in welfare, interest has shifted to documenting and analyzing what individual household members own, earn, and spend, as well as who makes key decisions in the household.

There is a clear rationale for objective, quantitative documentation of gender discrepancies: the design and evaluation of projects and policies should be based on sound evidence rather than myths (Quisumbing et al., 2014; Doss et al., 2015). Assuming they are potentially strong indicators of women's empowerment, survey questions designed to assess detailed individual (sole or joint) asset ownership and participation in productive and reproductive decisions are now increasingly standardized. In a rural context, the economic literature often focuses on the residence and agricultural land as key assets of interest (Deere and Doss, 2006; Kieran et al., 2017), and on decision-making in agriculture and household affairs (Doss and Quisumbing, 2018, In press; Ambler et al., In press).

A substantial literature has developed that uses these quantitative data to analyze patterns of gender disparities and women's empowerment, but at the same time studies have reflected on which measures are better able to capture women's empowerment (e.g., Kabeer, 1999; Hanmer \& Klugman, 2016; Meurs \& Ismaylov, 2019). While it may be true that measurement itself is feasible and can be standardized, interpretation of the indicators may not be as standard as one would expect. What matters is often context-specific, and how to interpret the data may also be context-specific (Akter et al., 2017).

Geographically, gender-oriented studies that feature commonly in the development literature originate from Sub-Saharan Africa, South Asia, and to a limited extent from Latin America. Much less is known about Southeast Asia (Kieran et al., 2015; Akter et al., 2017). Yet, it is widely acknowledged that there are no blanket recommendations for gender equality. Southeast Asia and the different countries it encompasses are in many aspects culturally distinct from other geographical areas that have been more extensively studied, including neighboring or nearby countries such as Bangladesh, India, and Nepal. This begs the question of whether conclusions drawn from other regions are relevant in the Southeast Asian context.

In this paper we focus on Myanmar. Gender equality in Myanmar is a topic of considerable controversy and debate. In the past, Myanmar was often praised for its apparent gender equality. Dr. Maung, a 
renowned lawyer and historian wrote that "[...] in matters of inheritance and property there is no country where the principle of equality of the sexes has been carried further than in Burma." (Maung, 1963, p. 63). Tharaphi Than (2014, p.173) though contradicts this: "We repeat the old message that women are being regarded as equal to men and Burmese women enjoy equal status to men in our society, even though the available data tell us otherwise." In contrast to the gender debate in many other countries, the debate in Myanmar does not center around how to address gender equality, but first and foremost it questions whether gender equality or a sufficiently close approximation of gender equality is not already present in its society.

In this paper, we combine qualitative and quantitative analyses of asset ownership and decision-making in households to explore the meaning and the extent of the gender gap in asset ownership in rural Myanmar. The objective of this work is threefold. First, we aim to understand the context of asset ownership in Myanmar through a literature review and qualitative field work in the country. Second, we quantify gender gaps in asset ownership (i.e., housing and land) in rural Myanmar. This fills part of the evidence gap for Southeast Asia in general, and for Myanmar specifically. Third, we combine these insights to reflect whether popular feminist economic thinking is appropriate for the Southeast Asian context and to draw lessons for future quantitative analyses of gender discrepancies in Southeast Asia.

\section{Empowerment and equality in asset ownership}

Much of the current feminist economics thinking is shaped by Kabeer's concept of women's empowerment, based on three interrelated - yet indivisible - dimensions: resources, agency, and achievements (Kabeer, 1999). Resources include current and future access to resources, and broadly contain physical, human, and social resources. Agency relates to the ability to define one's goals and act upon them. It includes, but is not limited to, the process of decision-making. The achievement dimension contains the wellbeing outcomes of empowerment. In her paper, Kabeer uses this framework to reflect on various commonly used measures of empowerment. Several initiatives, such as the well-known Women's Empowerment in Agriculture Index (WEAl - Alkire et al., 2013) aim to capture essential components of this framework.

Asset data are relatively easy to collect and have therefore become often-used indicators representing either the resource dimension in Kabeer's framework or women's empowerment in general. Strong arguments, often accompanied by empirical evidence, suggest that women's asset ownership plays a significant role in improving women's productivity, equality, empowerment, or even women's wellbeing more generally (Agarwal, 1997; Deere and Doss, 2006; Doss, 2013). Assets are not only a useful source of 
material wealth or resources that enable income-generation, they also provide a safety net and are closely linked to status and power (Rao, 2017). Land is a particularly valuable resource in rural areas, and 'access to land' is often considered a valid indicator for women's empowerment. Housing, though less researched in rural settings, is another key asset, especially in the presence of a large landless population as in many South and Southeast Asian countries. A house provides not only shelter, houses are often also productive assets; for example, they can be a host of a small enterprise, rented out, used as collateral for credit, or even sold to obtain cash (Datta, 2006; Deere and Doss, 2006).

Two institutions are believed to be of primary importance for women's asset ownership: marriage and inheritance (Agarwal, 1997; Deere and Doss, 2006). Both statutory and customary laws related to marriage and inheritance have a substantial impact on women's asset ownership. Yet, even where statutory laws are put in place, customary laws, social norms, and traditions often continue to dominate the allocation rules at critical times in the life cycle of men and women (e.g., Mishra and Sam, 2016 for Nepal; or Datta, 2006 and Deininger et al., 2010 for India). In many societies, land is not primarily perceived to be an individual household asset, but a resource that belongs to a family, lineage or community (Rao, 2006). Customary laws related to property rights at marriage or inheritance should therefore be understood within the context of kinship and lineage, which defines who belongs to the group that has rights to this resource (Lambrecht, 2016).

In Bangladesh, for example, statutory laws are in place that allow women to own property and that are effectively gender-equal. Islamic law allows property ownership for women, and states that daughters will inherit, though they can inherit only half of the share of sons in the household (Agarwal, 1994; Kieran et al., 2015). However, according to customary laws, families and therefore property rights are organized through a patrilineal and patrilocal kinship system (Kieran et al., 2015). In practice, women's rights to own land are little respected, and there is a strong male-bias in property ownership both through inheritance and when dividing property at divorce (Agarwal, 1994; Kieran et al., 2015). Similarly, most communities in Nepal are organized through patrilineal kinship systems. With inheritance being the main mode of access to land, women in Nepal have limited land rights (Allendorf, 2007). Daughters only have the right to their father's property as long as they are unmarried, and women have the right to only a share of their husband's property (Allendorf, 2007).

Even when neither statutory nor customary laws directly discriminate based on gender, social norms can still impede women's access to land or property or undermine the potential positive impact of women's property rights on empowerment (Agarwal, 1994, 1997; Doss and Quisumbing, 2018). The social legitimacy of claiming a certain asset may be as much if not more important than the legal validity of the 
claim (Agarwal, 1994; 1997). Patrilocal settlement patterns, for example, may cause women to move further away from their maternal homes after marriage and therefore prevent women from exercising their claims to residential or agricultural land which may be perceived too far away for them to live, manage, or cultivate by themselves. Gender stereotypical images of men as breadwinners and women as caretakers are often-used justifications for unequal property rights (Lambrecht, 2016; Doss and Quisumbing, 2018). What is considered appropriate behavior for men and women, for example related to freedom of movement, may also be considered legitimate reasons for withholding women's property rights (Agarwal, 1997). In the Philippines, which has a partible and bilateral inheritance system, Quisumbing, Estudillo, and Otsuka (2004) note that gendered inheritance patterns are motivated by perceptions of comparative advantage and work effort. Whereas girls are less likely to inherit land, parents invest more in daughters' schooling as compared to that of sons, essentially leading to equitable inheritance patterns.

Social norms and what are considered 'customary practices' are also subject to change, often alongside or as a consequence of other major shifts in the society (Quisumbing et al., 2004). These shifts in society can be due to evolving statutory law as well as economic transformation, such as increased urbanization or accelerating or decelerating rates of migration. The drive towards formalization of land ownership, for example, has been met with concern that women or disadvantaged groups may lose rather than gain reinforced land rights (Lastarria-Cornhiel, 1997). To the contrary, Quisumbing and Otsuka (2001) found the opposite in Sumatra, Indonesia, where the change from communal to individualized land tenure resulted in more equal inheritance patterns. The inheritance regime in Sumatra shifted from a strictly matrilineal inheritance regime to a bilateral inheritance regime which divides land between sons and daughters according to the predominant gender division of labor in agriculture. Several governments have used the opportunity of formalization to strengthen women's property rights by including women's names on land or house certificates, for example in Peru (Wiig, 2013) or India (Datta, 2006).

\section{Research approach and methods}

This paper draws on a review of the existing literature on gendered access to assets in rural Myanmar, and on both qualitative and quantitative data. Qualitative research was conducted between January and July 2019 using gender-separated focus group discussions and individual interviews. All qualitative field work took place in the presence of one of the authors. The focus of the qualitative research was on household formation, asset ownership, and economic activity throughout the life cycle of men and women. A first set of semi-structured interviews and group discussions were conducted near Yangon with the aim to refine the interview guidelines. Further qualitative field work took place in the areas where a 
broader research project had formerly conducted surveys (Mon State, Delta, Dry Zone, and Southern Shan State), yet recognizing that the sample was lacking a diversity of religious groups, we purposively included qualitative field work in Bago. In total, 54 individual interviews and 31 focus group discussions were conducted in 13 different townships and five state/regions, with people from ten different ethnic groups in Myanmar. All interviews were recorded and transcribed.

The quantitative analysis is mainly descriptive ${ }^{1}$ It is based on data from the Myanmar Poverty and Living Conditions Survey (MPLCS) conducted between January and April 2015. The MPLCS is a nationally representative dataset consisting of information for 3,648 households in total, and 2,364 rural households in particular. Whereas this dataset contains a relatively small sample, it comprises much richer information on gender and asset holdings in rural areas compared to other recent nationally representative datasets. The MPLCS survey is representative at the level of the four main agro-ecological zones (Coastal, Dry Zone, Delta, Hills and Mountains) and Yangon, but not at either the state/region level or the urban/rural level of agro-zones.

It is important to bear in mind that neither the qualitative nor quantitative analyses in this paper are able to capture all possible differences in gendered social norms and gender discrepancies that exist across Myanmar's diverse ethnic and religious landscape. The level of detail included in the available quantitative datasets also presents shortcomings. Whereas the MPLCS data contains a wealth of gender-disaggregated information, it was not able to capture all we would ideally have quantified. For example, the data reports documented ownership, but enumerators were not asked to specify which kind of document they had nor to verify the document itself to see whether the name of the person on the certificate was correctly identified by the respondent. Moreover, some questions, such as who has use rights to the land, are not asked for parcels with a land certificate. Finally, the dataset does not identify the respondent to parcellevel questions. Other studies have shown that the gender of the respondent affects answers on ownership and decision-making (Twyman et al., 2015; Ambler et al., In press).

\section{Qualitative Results and anthropological literature}

Most ethnic groups in Myanmar, including many ethnic minority groups, do not identify with a patrilineal or a matrilineal kin group, nor do they worship ancestors or follow a system of family names (Maung , 1963 p.6; Murdock, 1967 pp. 90-93). ${ }^{2}$ This absence of a strong role of kinship or lineage in common

\footnotetext{
${ }^{1}$ Originally the authors envisioned regression analyses exploring factors associated with land ownership. In practice though multicollinearity with the role in the household, in particular household headship or spouse of head, is too strong.

${ }^{2}$ Well-known exceptions are the Kachin and Chin people (Murdock, 1967, p. 90-93)
} 
practices stands in sharp contrast with most societies in developing countries studied by feminist economists. Below we discuss two key institutions that affect asset ownership - marriage and inheritance - as well as gender patterns in rural households and communities that are relevant to better understanding the linkages between asset ownership and empowerment.

\subsection{Marriage and inheritance}

There is no formal statutory law governing general marriages in Myanmar. ${ }^{3}$ Marriage, divorce, and inheritance practices must follow the customary law governing each citizen, and for the majority of households in Myanmar this is the "Myanmar Customary Law" (also popularly known as the "Burmese Buddhist Law"). ${ }^{4}$ There are no overt gender discriminatory practices in the Myanmar Customary Law (Maung, 1963, p. 49-50).

For a man and woman to marry, mutual consent is needed from both spouses and consent is usually also obtained from parents and elders. Arranged marriages are rare in all communities we visited, except for the Hindu communities. ${ }^{5}$ The phenomenon of 'running away' or 'eloping' of couples who are afraid to ask for or were unable to obtain consent to marry from parents is frequent and well-known throughout the country. Shortly after eloping, parents generally convince their children to return to their natal homes, and in order to avoid any dishonor the parents agree to the marriage (Khaing, 1984, p. 34; own interviews).

Marriage in Myanmar is often being described as "a partnership in goods, vesting an equal interest in each spouse" (Maung, 1963, p. 7). In general, all properties acquired by the spouses during their marriage are considered joint property and belong equally to the husband and wife. If one spouse dies, all properties remain with the surviving spouse. In nearly all communities that we visited, a woman will become the sole owner of the property when her husband passes away. Exceptions include cases where the marriage was recent or where there are prospects for re-marriage of the surviving spouse. This was also found in several communities that have different customary laws and where women inherit few or any properties from their family compared to their male siblings.

In most ethnic and religious groups, there is no tradition of bride prices or dowries. ${ }^{6}$ The newly-weds also do not generally expect to receive major assets, such as land or housing, from parents or other relatives at or around their wedding date. Rather, young couples typically live with family after their marriage to

\footnotetext{
${ }^{3}$ The exceptions of the "Special Marriage Act" for interreligious marriages and the "Monogamy Law" which forbids polygamy.

${ }^{4}$ The two other most common systems are the Anglo-Muhammadan law and the Anglo-Hindu law (Maung, 1963).

${ }^{5}$ Exceptions are, for example, the ethnic Chin people (Boutry et al., 2018).

${ }^{6}$ An exception again are, for example, the Chin people in Myanmar (Boutry et al. 2018).
} 
accumulate sufficient savings to start their own household or until they feel the need to establish their own household. Parents materially support their children in establishing their own households or transfer land to their children when they form their own separate households only if deemed necessary and if they can afford to do so.

Whose family the couple will stay with after the marriage varies across different locations in Myanmar, yet practical considerations override traditions in choosing where the young couple will temporarily and later also more permanently establish their household. We find matrilocal, patrilocal, or no traditional/default settlement pattern at all. A female respondent in Mon State explained the choice of residence after marriage as follows: "According to the tradition, we lived seven days in my parents" house and then three days in my husband's parents' house. After that, we lived for one year in my parents' house to take care of my sisters who were young and single at the time of our marriage. Moreover, paddy fields were only available from my side for our occupation. My husband's parents do not have paddy fields and could not provide any occupation for us. After one year living at my parents' house, we lived in a separate house to make it more convenient for my sisters if they will get married." It is not uncommon for husband and wife to live separately at each spouse's parents' home until they are able to 'split off' and form their own household.

Similar to marriage, divorce must take place based on mutual consent to end the marriage. Divorce is, however, rare, and parents and elders will intervene and provide advice to avoid a divorce as much as possible. Being a rarity, rules on the division of property upon divorce, if any, are not easy to infer. Many respondents indicated that properties would be distributed equally among spouses upon divorce, in some cases taking into account the presence of children while in other cases not.

Parents do not generally bequeath their properties when they are still alive. Wills are not written, yet parents can organize in vivos transfers of property. In principle, children can expect equal inheritance regardless of their gender. Yet, the family may deviate from equal inheritance based on the current or forecasted economic status of the children in an attempt for a more equitable (as opposed to equal) division of property. A comprehensive and detailed overview on land inheritance patterns in the Dry Zone and Delta of Myanmar has been documented by Boutry et al. (2017). Their findings are in line with the stories we heard from these areas and to a large extent also similar to the inheritance patterns we found in the interviews in Shan and Mon State. 


\subsection{Gender patterns in the household and community}

By default, men are considered the head of the household. Men are traditionally reported as representatives of their household in the community registry, and consequently their names are often automatically deemed appropriate on formal documentation of household properties or agricultural land. Across communities, perceptions vary over the role and meaning of headship, and several respondents explained headship to be a mere 'paper' formality. Nevertheless, their wives - not their eldest or residing son - will be the acting heads of households when their husbands pass away or are in poor health.

The practice of reporting only one name - mainly the men's name - on formal ownership documents easily raises valid concerns of lending full property rights to only one person. In practice though, none of the respondents agreed that this person could therefore dispose of any asset - documented or not without consent from other household members. Instead, they emphasized the need for agreement in the household. A male respondent in a focus group discussion in Shan State mentioned: "We have to write only the household head's name [on the Form 7]. Even if we write only our name on the Form 7, it is concerned with both of us, me and my wife."

Household members make a deliberate choice whose name to include on the land certificate. This decision is based not only on who traditionally or officially is considered the household head but also in part on practical considerations such as who is deemed most appropriate to visit a bank or another official agency that requires proof of certification. Formal land titling and access to credit are strongly linked in Myanmar. Following the rules of the Myanmar Agricultural Development Bank (MADB), access to a loan is only possible upon presentation of a land title certificate (Form 7) in the same name as the person applying for the loan. A male respondent in a group discussion near Yangon mentioned: "Mostly, it [Form 7] is in the name of the household's head, usually a male, because the husband goes to bank to get a loan, goes to offices, or attends meetings for matters relating to their agricultural land, while the wife stays at home and is doing household work and taking care of children." Men are often perceived to be better able to manage official affairs, which respondents explained is either due to a perception that men are more skilled or apt at such formalities, or that women's strong commitments to reproductive tasks at home do not allow them to easily visit official agencies. That practicalities rather than tradition dominate the decision of whose name should be written on the land certificate is also illustrated by the following remark by a man near Yangon: "In households which own more than 10 acres of agricultural land, they make two or more Form 7s for their land. One is in the husband's name, the others are in the name of the wife or in the names of their children, because agricultural loans are limited to 10 acres per household". 
There is a strong focus on harmony in households and on avoiding conflict or disagreement. Individualization of property or income is not common. Generally, all household members pool their income, which is then managed by either the husband or wife. There is no tradition of 'men's plots and women's plots', 'separate pockets', or similar arrangements to an extent similar to that found in many other countries. Women are generally perceived to be better managers of household income compared to men and therefore also generally manage the income of all household members. This statement from a female respondent in Mon State illustrates this: "We have only one source of income, which is rubber. After selling the rubber flats, my husband gives me all the money with an invoice. He does not keep the money for himself. I manage this money for the household's expenditure. If my husband needs money, he asks me for it. Often, he asks for 1000 - 1500 kyats to go to the tea shop. I don't refuse to give it to him because I know he never uses it for unnecessary things or for fun." Another female respondent in Mon State mentioned the following regarding decision-making on household finances: "We discuss it with each other. If we don't have enough money for it, we find ways together."

Despite the narrative of equality, we find a classic gender division of tasks where women primarily take care of the household (childcare, cooking, washing) whereas men are considered to act as the main income provider for the household. Several tasks that require more strength or technical skills, such as plowing or uprooting, are considered men's work. Women's tasks are those that are perceived to require more patience but less strength, such as weeding or transplanting. In some areas women primarily stay at home, even in the absence of children or elders to care for. In other regions, women are very active both in farm management and providing labor to the household's farm (the latter, for example, when men are fishing) or as daily wage workers.

In most communities, there are no strong norms similar to the purdah in Bangladesh or parts of India that severely restrict women's movement, though clear exceptions are present in the Muslim and Hindi communities in Myanmar. Both men and women migrate; however, migration is primarily limited to younger adults. Young couples often jointly migrate, or the couple is formed at the migration destination. In some Dry Zone communities, respondents stated that women are the main seasonal migrants during the dry season while men stay home to plough their fields, which is typically a man's job. Despite the absence of strong gendered mobility restrictions, there are ample communities where women 'selfrestrict' their movements. Women are more likely to be concerned that their behavior incites gossip and to feel more vulnerable at night or in unfamiliar settings. In all communities, even where there were no reported past incidents or current threats, such perceptions of vulnerability more strongly limit women's mobility as compared to men's mobility. 


\section{Quantitative Results}

\subsection{Rural households in Myanmar: the 'gender' scene in numbers}

According to the 2014 census, 70 percent of the population in Myanmar lived in rural areas and more than half of the population consisted of women (52 percent) (Department of Population (2015). Table 1 shows an overview of key characteristics of rural households in Myanmar derived from the MPLCS data. A household head is on average 50 years old, and in nearly one in five households (19 percent), the household head is female. There are no rural households in the MPLCS dataset where a husband lives with multiple wives in the same household. However, this may not fully align with the absence of polygamy, as men in polygamous marriages may have wives in what are considered to be distinct households. Using the Myanmar Demographic and Health Survey (2015), we find that 4 percent of married men below 49 years of age in rural areas report having multiple wives. Yet, these men generally do not live together with multiple wives in the same household.

Household sizes are moderate, on average consisting of 5 household members including one child under 15 years of age (Table 1). About 10 percent of households consist of a single individual or the primary couple (head and spouse) without children or other adults. We find a nuclear household structure, consisting of parents and their own children, in nearly two-thirds of households (63 percent), and an extended household composition, including other adults who are not children of the household head or spouse, in 28 percent of rural households. Matrilocal and patrilocal residence patterns occur at equal rates, with 12 percent of married adults living respectively with the wife's or husband's parent(s).

Table 1: Characteristics of rural households

\begin{tabular}{lc}
\hline & Mean \\
\hline Female household head & 0.19 \\
Age of the household head (years) & 50 \\
Average household size & 4.5 \\
Average number of adult women & 1.7 \\
Average number of adult men & 1.4 \\
Average number of children under 15 & 1.4 \\
Household structure: Single/primary couple with no children & 0.10 \\
Household structure: Head (and spouse) with children & 0.63 \\
Household structure: Head (and spouse/children) plus other adults & 0.28 \\
Rural households (number of observations) & 2,316 \\
\hline
\end{tabular}




\subsection{Assets}

Tables 2-9 report on ownership of two key assets in rural areas: housing and landholdings. For these assets, where relevant we look at reported and documented ownership. We also consider the gender of the owners in terms of being male or female, as well as in terms of their role in the household: being the household head, the head's spouse, or other family.

\subsubsection{Housing}

Nearly all households (95 percent) own the house in which they live (Table 2). Female-headed households are not less likely than male-headed households to own their house. Respondents most frequently reported that the house was owned jointly by men and women (58 percent), and only slightly more often by men ( 23 percent) compared to women ( 20 percent). In nearly all households, the reported owner is the household head, either solely or jointly with a spouse. The cases in which the spouse of the household head or another family member are the owners are rare.

Among the households who own their house, only 26 percent have ownership documents. Again, femaleheaded households are not less likely to have ownership documents compared to male-headed households. The share of male owners is much higher than the share of female owners (resp. 39 percent and 19 percent), but mixed ownership is still more common (42 percent). Documented ownership ${ }^{7}$ is generally in the name of the household head (55 percent) or both the household head and spouse (27 percent). Only in 3 percent of the cases documentation is in the name of the spouse of the household head, and more often it is in the name of another family member (15 percent).

\footnotetext{
${ }^{7}$ Note that this should be considered as the 'reported documented ownership' since the enumerators were not required to verify the responses by reviewing the ownership documents. Given that ownership documents typically do not allow for more than one name, it is unlikely that more than one name is written on this document. We interpret this discrepancy of two names on the documents of further evidence that couples regard housing as jointly owned, regardless of which name is written on the documents.
} 
Table 2: Reported and documented house ownership for rural households

\begin{tabular}{|c|c|c|c|c|c|}
\hline & & & & hold hea & \\
\hline & & All & Male & Female & \\
\hline Household owns hou & $2,316)$ & 0.95 & 0.95 & 0.96 & \\
\hline If owned, $(N=2,184)$ : & & & & & \\
\hline Declared owner & Men only & 0.23 & 0.28 & 0.00 & $* * *$ \\
\hline & Women only & 0.20 & 0.02 & 0.90 & $* * *$ \\
\hline & Men and women & 0.58 & 0.70 & 0.10 & $* * *$ \\
\hline & Household head & 0.43 & 0.30 & 0.97 & $* * *$ \\
\hline & Head's spouse & 0.01 & 0.01 & 0.00 & $* * *$ \\
\hline & Couple & 0.54 & 0.67 & 0.01 & $* * *$ \\
\hline & Other family & 0.02 & 0.02 & 0.02 & \\
\hline If so, household has $c$ & ip documentation & 0.26 & 0.26 & 0.27 & \\
\hline If household has any & ntation $(N=548)$ : & & & & \\
\hline Documented owner & Men only & 0.39 & 0.48 & 0.01 & $* * *$ \\
\hline & Women only & 0.19 & 0.05 & 0.73 & $* * *$ \\
\hline & Men and women & 0.42 & 0.46 & 0.25 & $* * *$ \\
\hline & Household head & 0.55 & 0.50 & 0.75 & $* * *$ \\
\hline & Head's spouse & 0.03 & 0.04 & 0.00 & $* * *$ \\
\hline & Couple & 0.27 & 0.34 & 0.01 & $* * *$ \\
\hline & Other family & 0.15 & 0.12 & 0.24 & $* * *$ \\
\hline
\end{tabular}

Note: Stars denote significant differences between households with male and female headship at ${ }^{*} p<0.10 ;{ }^{* *}$ $p<0.05 ; * * *<<0.01$

Table 3 compares reported ownership and documented ownership among households who have house documents. Reported ownership is more often joint ownership compared to documented ownership; 17 percent report joint ownership by the household head and his spouse when the documents only mention the name of the household head. Moreover, in 8 percent and 5 percent of the cases the household head or the primary couple declare themselves to be the houseowners whereas another family member's name is written on the ownership documents. In other words, 50 percent report joint ownership even though only 27 percent report having both names on the document. These results confirm the qualitative field work findings: documented ownership does not closely align with perceived ownership and reinforces the narrative that the name of the household head on property documents signals household-level ownership rather than individual ownership. Family members often do not consider it necessary to change ownership documents when a house is passed on from one member to another. 
Table 3: Comparison of reported and documented house ownership for rural households ( $N=548$ )

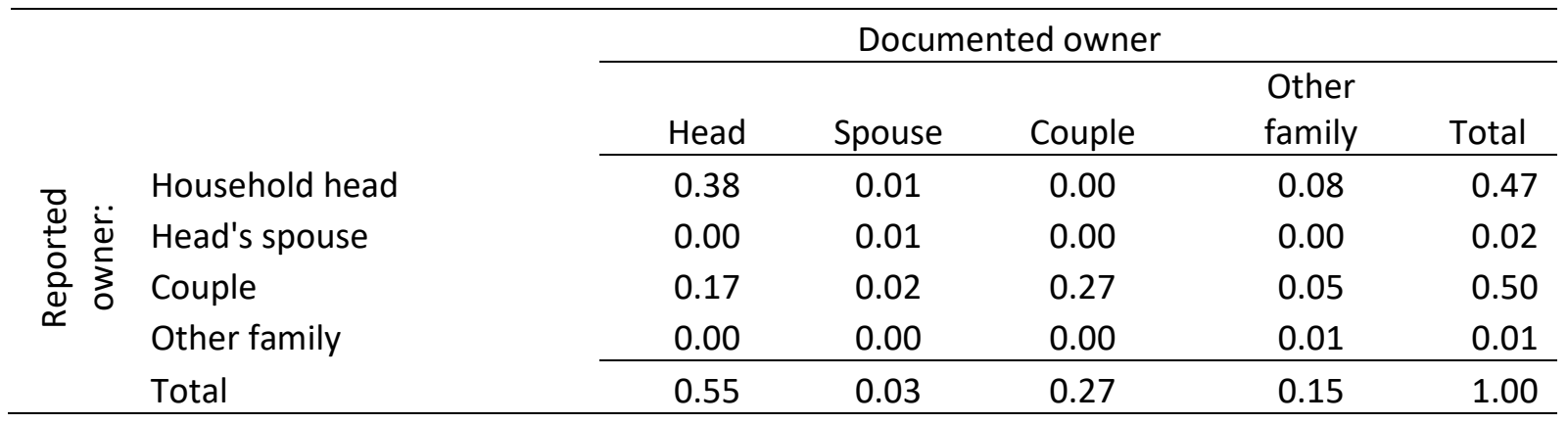

\subsubsection{Ownership and use rights of agricultural land}

Myanmar has a large rural landless population and rental land markets are thin. Only half of all households in rural areas own agricultural land, and slightly more households cultivate land (50 percent and 52 percent, respectively) (Table 4). A majority (87 percent) of all cultivated parcels are owned by the household, 6 percent are borrowed or leased in without charge, whereas only 4 percent are rented in. The share of cultivated agricultural parcels sharecropped ( 2 percent) or reported to be communal land ( 1 percent) is small. Compared to the small rental market, however, a relatively large share of parcels is acquired through purchase. Just more than half (51 percent) of owned agricultural parcels are inherited, whereas 39 percent are purchased by the owners.

Female-headed households are less likely to own or cultivate land (49 percent) compared to male-headed households (59 percent) (Table 4). Whereas the gender gap in terms of land ownership (based on household headship) is relatively small ( 45 for female- versus 51 percent for male-headed households), it is much larger when considering the share of households who cultivate land (40 versus 55 percent). Female-headed households are thus significantly more likely to rent or lend out the agricultural land that they own compared to male-headed households (13 versus 5 percent).

The mode of access to cultivated parcels is not much different between male- and female-headed households (Table 4). Cultivated parcels in female-headed households are more likely to be owned and less likely to be rented in, though the differences are not very sizeable (resp. 4 and 3 percent). Parcels owned by female-headed households are more likely acquired through inheritance and less likely through purchase. Around three-quarters of all agricultural parcels owned also have a certificate, and this does not differ significantly depending on headship 
Table 4: Access and mode of acquisition of agricultural land in rural areas

\begin{tabular}{|c|c|c|c|c|}
\hline & \multicolumn{4}{|c|}{ Household Head } \\
\hline & All & Male & Female & \\
\hline \multicolumn{5}{|l|}{ Share of rural households $(N=2,316)$} \\
\hline Own or cultivate land & 0.57 & 0.59 & 0.49 & $* * *$ \\
\hline Own land & 0.50 & 0.51 & 0.45 & $* *$ \\
\hline Cultivate land & 0.52 & 0.55 & 0.40 & $* * *$ \\
\hline \multicolumn{5}{|l|}{ Mode of access to cultivated parcels $(N=2,208)$} \\
\hline Owned & 0.87 & 0.86 & 0.90 & $*$ \\
\hline Borrowed & 0.06 & 0.06 & 0.06 & \\
\hline Rented & 0.04 & 0.05 & 0.02 & $* * *$ \\
\hline Sharecropped & 0.02 & 0.02 & 0.03 & \\
\hline Communal & 0.01 & 0.01 & 0.00 & \\
\hline \multicolumn{5}{|l|}{ Mode of acquisition of all owned parcels $(N=2,092)$} \\
\hline Inherited & 0.51 & 0.48 & 0.61 & $* * *$ \\
\hline Purchased & 0.39 & 0.41 & 0.27 & $* * *$ \\
\hline Cleared land/occupied for free & 0.08 & 0.08 & 0.11 & \\
\hline Given by the state/local authority & 0.02 & 0.02 & 0.02 & \\
\hline Gift from friend or relative & 0.01 & 0.01 & 0.00 & $* * *$ \\
\hline Share of owned parcels that have certificates & 0.74 & 0.74 & 0.76 & \\
\hline \multicolumn{5}{|c|}{$\begin{array}{l}\text { Note: Stars denote significant differences between households with male and female headship at }{ }^{*} p<0.10 ;{ }^{* *} \\
p<0.05 ;{ }^{* *} p<0.01\end{array}$} \\
\hline \multicolumn{5}{|c|}{ In Table 5, we look at land rights based on gender (exclusively male, exclusively female, or joint) on the } \\
\hline \multicolumn{5}{|c|}{ one hand, and on the role within the household (head, spouse, primary couple, or other family) on the } \\
\hline \multicolumn{5}{|c|}{ other hand. For parcels with a certificate, the MPLCS survey asks whose name is written on the certificate; } \\
\hline \multicolumn{5}{|c|}{ if there is no certificate, it asks who has the use rights to the parcel. Who has the right to sell the parcel is } \\
\hline \multicolumn{5}{|c|}{ asked for all owned parcels. A majority of households (53 percent) report that both men and women have } \\
\hline \multicolumn{5}{|c|}{ the right to sell the parcel, and this percentage is higher in male-headed households (60 percent). About } \\
\hline \multicolumn{5}{|c|}{30 percent of agricultural parcels can be sold exclusively by men, whereas only 17 percent of parcels can } \\
\hline be sold by women only. The latter is mainly dri & in fer & ded hou & holds. H & ship is \\
\hline ell. Agricultu & Cdn & טלנ & Dy tre & \\
\hline 1 & & & & \\
\hline
\end{tabular}


Table 5: Reported and documented land rights for owned agricultural land

\begin{tabular}{|c|c|c|c|c|c|c|c|c|c|c|c|c|}
\hline & \multicolumn{4}{|c|}{$\begin{array}{l}\text { Parcels without certificate: } \\
\text { Use rights }\end{array}$} & \multicolumn{4}{|c|}{$\begin{array}{l}\text { Parcels with certificate: } \\
\text { Certificate holder: }\end{array}$} & \multicolumn{4}{|c|}{$\begin{array}{l}\text { All parcels: } \\
\text { Right to sell }\end{array}$} \\
\hline & All & $\begin{array}{l}\text { Male } \\
\text { head }\end{array}$ & $\begin{array}{l}\text { Female } \\
\text { head }\end{array}$ & & All & $\begin{array}{l}\text { Male } \\
\text { head }\end{array}$ & $\begin{array}{l}\text { Female } \\
\text { head }\end{array}$ & & All & $\begin{array}{l}\text { Male } \\
\text { head }\end{array}$ & $\begin{array}{l}\text { Femal } \\
\text { head }\end{array}$ & \\
\hline Men only & 0.33 & 0.38 & 0.10 & $* * *$ & 0.62 & 0.73 & 0.08 & $* * *$ & 0.30 & 0.36 & 0.04 & $* * *$ \\
\hline Women only & 0.13 & 0.02 & 0.77 & $* * *$ & 0.19 & 0.05 & 0.83 & $* * *$ & 0.17 & 0.05 & 0.79 & $* * *$ \\
\hline Men and women & 0.53 & 0.61 & 0.12 & $* * *$ & 0.19 & 0.21 & 0.09 & $* * *$ & 0.53 & 0.60 & 0.17 & $* * *$ \\
\hline Household head & 0.46 & 0.39 & 0.86 & $* * *$ & 0.74 & 0.72 & 0.84 & $* * *$ & 0.45 & 0.37 & 0.89 & $* * *$ \\
\hline Head's spouse & 0.01 & 0.01 & 0.00 & $* * *$ & 0.02 & 0.03 & 0.00 & $* * *$ & 0.04 & 0.04 & 0.00 & $* * *$ \\
\hline Couple & 0.50 & 0.58 & 0.01 & $* * *$ & 0.17 & 0.20 & 0.01 & $* * *$ & 0.47 & 0.56 & 0.01 & $* * *$ \\
\hline Other family & 0.03 & 0.01 & 0.13 & $* * *$ & 0.07 & 0.06 & 0.15 & $* * *$ & 0.04 & 0.03 & 0.10 & $* * *$ \\
\hline $\begin{array}{l}\text { Nr of } \\
\text { observations }\end{array}$ & 635 & 538 & 95 & & 1,457 & 1,214 & 243 & & 1,851 & 1,560 & 291 & \\
\hline
\end{tabular}

Note: Stars denote significant differences between households with male and female headship at ${ }^{*} \mathrm{p}<0.10 ;{ }^{* *}$ $\mathrm{p}<0.05 ; * * * \mathrm{p}<0.01$

It is informative to compare the responses to the three questions (who has use rights, who is the certificate holder, and who has the right to sell) in Table 5. When looking at who has use rights when there is no land certificate, we find a much higher share of parcels with joint rights by men and women (53 percent) or by the primary couple (50 percent). Yet, when asking whose name is on the land certificate respondents more often report "men only" and "household head" (62 percent and 74 percent, respectively). The responses to who has the right to sell a plot are more similar to the question of who has use rights compared to the answers to whose name is on the certificate; the rights to sell are mainly held jointly by men and women ( 53 percent) and by the primary couple ( 47 percent).

Table 6 further explores this comparison by cross-tabulating the documented owners and reported use right holders with who has the rights to sell the land, based on the role in the household. Such comparisons are expected to come with a certain level of discrepancy, yet the share of parcels with discrepancies is much higher when tabulating documented ownership (rather than use rights) with rights to sell. We find a relatively large shift from the head being the documented sole owner on the certificate to the primary couple jointly having the right to sell the owned land.

Table 6 also sheds light on the question of whether land certificates are possibly associated with a larger gender gap in rights to sell the parcel. We find a higher share of parcels where husbands and wives jointly have the rights to sell the parcel when the parcel does not have a land certificate (i.e., 53 percent versus 45 percent), yet this is mostly driven by a larger share of other family members or the head's spouse having the rights to sell a parcel but not by a significantly larger share of household heads who have the rights to sell when there is a land certificate. 
Table 6: Cross-tabulation of who has right to sell with documented owner or reported use rights

\begin{tabular}{|c|c|c|c|c|c|c|c|c|c|c|}
\hline & \multicolumn{6}{|c|}{ Use right - no certificate $(\mathrm{N}=495)$} & \multicolumn{4}{|c|}{ Documented owner $(\mathrm{N}=1,356)$} \\
\hline & All & Head & Spouse & Couple & Family & $\mathrm{All}^{\mathrm{a}}$ & Head & Spouse & Couple & Family \\
\hline \multirow{4}{*}{ 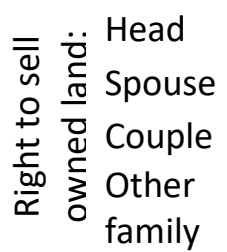 } & 0.44 & 0.38 & 0.00 & 0.04 & 0.02 & 0.46 & 0.41 & 0.00 & 0.00 & 0.04 \\
\hline & 0.02 & 0.00 & 0.00 & 0.01 & 0.00 & $0.04^{* *}$ & 0.03 & 0.01 & 0.01 & 0.00 \\
\hline & 0.53 & 0.08 & 0.01 & 0.45 & 0.00 & $0.45^{* * *}$ & 0.28 & 0.01 & 0.16 & 0.00 \\
\hline & 0.01 & 0.00 & 0.00 & 0.00 & 0.01 & $0.05^{* * *}$ & 0.02 & 0.00 & 0.00 & 0.04 \\
\hline
\end{tabular}

\subsubsection{Decision-making on agricultural parcels}

Parcel management decisions ${ }^{8}$ are mostly made by men only (45 percent), or by men and women jointly (42 percent), and only 13 percent are managed exclusively by women (Table 7). The discrepancy is more extreme when we consider the role of the person in the household. More than half of the parcels are managed by the household head alone ( 55 percent), over a third ( 37 percent) by the primary couple, but nearly no parcels (1 percent) by the head's spouse. Women who are not the head of a household hence rarely are sole decision-makers on an agricultural parcel.

Table 7: Parcel management decisions on agricultural parcels

\begin{tabular}{|c|c|c|c|c|}
\hline \multirow[b]{3}{*}{ Exclusively male } & \multirow[t]{2}{*}{ All } & \multicolumn{2}{|c|}{ Household head } & \\
\hline & & Male & Female & \\
\hline & 0.45 & 0.52 & 0.13 & $* * *$ \\
\hline Exclusively female & 0.13 & 0.02 & 0.70 & $* * *$ \\
\hline Male and female & 0.42 & 0.47 & 0.17 & $* * *$ \\
\hline Household head & 0.55 & 0.51 & 0.76 & $* * *$ \\
\hline Head's spouse & 0.01 & 0.01 & 0.00 & $* * *$ \\
\hline Couple & 0.37 & 0.44 & 0.01 & $* * *$ \\
\hline Other family & 0.07 & 0.04 & 0.23 & $* * *$ \\
\hline Number of observations & 2,412 & 2,034 & 378 & \\
\hline
\end{tabular}

Note: Stars denote significant differences between households with male and female headship at * $p<0.10 ; * * p<0.05 ; * * * p<0.01$

Who makes the main parcel management decisions does not necessarily coincide with who has ownership rights over the parcel (Table 8 ). A large proportion (15 percent) of parcels is managed mainly by the household head, yet rights to sell the same parcel are jointly held by the husband and spouse. We find

\footnotetext{
${ }^{8}$ The questionnaire asks who in the household makes decisions concerning the parcel and specifies that this can include crops to be planted, input use, decisions to sharecrop, rent etc.
} 
only few cases ( 3 percent) where the rights to sell a parcel are solely held by the household head, whereas management decisions are made jointly.

Table 8: Crosstabulation of parcel decision-making and right to sell for all owned parcels $(N=1,851)$

\begin{tabular}{clcccc}
\hline & & \multicolumn{4}{c}{ Right to sell } \\
& & Head & Spouse & Couple & Family \\
\cline { 3 - 6 } Parcel & Household head & 0.37 & 0.02 & 0.15 & 0.02 \\
decision- & Head's spouse & 0.00 & 0.00 & 0.00 & 0.00 \\
maker & Couple & 0.03 & 0.01 & 0.31 & 0.01 \\
& Other family & 0.05 & 0.00 & 0.00 & 0.02 \\
\hline
\end{tabular}

Note: Stars denote significant differences between households with male and female headship at ${ }^{*} p<0.10 ;{ }^{* *} p<0.05 ;{ }^{* * *} p<0.01$

We expect that a person working on a plot is more likely to also be involved in parcel management decisions. We therefore compare whether male and female adults in farm households were involved in any household agricultural activities with whether the person solely or jointly made decisions on at least one agricultural parcel (Table 9). Fewer women were involved in agricultural activities compared to men in the past 7 days (28 percent versus 47 percent), and overall women are less often the main decisionmakers on agricultural parcels compared to men (32 percent versus 59 percent). Yet, the proportion of women who do contribute work to household agricultural activities in the past 7 days but who are not the main parcel decision-maker is equal to the proportion of men who do work on the farm but are not main decision-makers (16 percent). We therefore do not find evidence that a disproportionate share of women work in household agricultural activities without taking part in agricultural decisions.

Table 9: Crosstabulation of own-farm work and parcel management decision-making by rural adults in households owning or cultivating land $(\mathrm{N}=4,221)$

\begin{tabular}{|c|c|c|c|c|}
\hline \multirow{5}{*}{$\begin{array}{c}\text { Person makes } \\
\text { decisions on a parcel } \\
\text { (solely or jointly) }\end{array}$} & \multirow{4}{*}{$\begin{array}{c}\text { Men } \\
(\mathrm{N}=1,946)\end{array}$} & \multirow[b]{3}{*}{ No } & \multicolumn{2}{|c|}{$\begin{array}{c}\text { Worked in household } \\
\text { agricultural activities in the } \\
\text { past } 7 \text { days }\end{array}$} \\
\hline & & & No & Yes \\
\hline & & & 0.24 & 0.16 \\
\hline & & Yes & 0.28 & 0.31 \\
\hline & Women & No & 0.51 & 0.16 \\
\hline & $(\mathrm{N}=2,275)$ & Yes & 0.20 & 0.12 \\
\hline
\end{tabular}




\section{Discussion}

\section{"[...] norms acting as hindrance to gender equality are not the only kind of gender norms that exist; there}

are also norms that support gender equality." (Pearse \& Connell, 2016, p.35)

The absence of a clear lineage or kinship system distinguishes the gendered context of Myanmar from more frequently described settings in countries in sub-Saharan Africa or South Asia. Most children in Myanmar do not take either their father's or mother's name, nor are they considered to belong to either their father's or their mother's bloodline. Consequently, marriage does not result in dramatic changes such as perceptions of men or women no longer belonging to their respective families or lineages. We do not only find this in the majority ethnic group, but also in many other ethnic and religious minority groups. The absence of strict traditions of matrilocality or patrilocality further dilute gender-biased practical considerations in terms of accessibility of land when bequeathing to sons or daughters. This and other unique features of communities in Myanmar allow for a property rights framework that does not openly discriminate by gender, with a joint property rights regime upon marriage and gender-equal inheritance practices.

It is true that we find a much larger share of male landowners compared to female landowners in rural Myanmar, yet the data confirm that it is generally the household head who is the reported and documented owner, either solely or jointly with the spouse. It is rare for a person who is not the household head to be considered the sole owner of a parcel - either based on who has use rights, who has the name on a certificate, or who has rights to sell the land. Whether a woman's name is documented as landowner may not matter all that much given the evidence that individuals do marry with joint property rights, that household members discuss and agree on all major transactions - such as buying or selling land, that property is shared equally upon divorce, that the surviving spouse rather than the children inherit all properties, and that children inherit equally regardless of their gender. Most rural respondents expressed no concerns over one person's name being used in formal property documentation.

Overlaying quantitative data with a qualitative understanding of the Myanmar context demonstrates that frequently used statistics such as incidence of landownership or distribution of landownership by sex of the owner, which are at first sight seemingly straightforward and objective numbers, do effectively signal different messages depending on the context. Many respondents in Myanmar tried to explain that which household member's name was on a land or house certificate did not matter, except in determining who was to go to the bank. The concept of assigning use or transfer rights of assets to individual household members does not align with local understanding of how households should behave. Yet, this stands in 
stark contrast with other settings, for example West-Africa where men and women manage different plots and often also keep their incomes separate from one another (Lambrecht, 2016).

Whereas the Myanmar context described above was depicted very positively, many concerns remain. Three distinct concerns clearly arose during the process of this research. First, several ethnic and religious minority groups in Myanmar do have social norms and perceptions that more strongly and overtly limit women's freedom of movement, property rights, and human rights in general (Gender Equality Network, 2015). Though our sample sizes are too small for firm conclusions, the data do hint at stronger male dominance in asset ownership and decision-making in some communities compared to others.

Second, as pervasive throughout so many cultures, men are regarded as the family breadwinners, spiritually more developed, or simply more skilled. Gender inequality persists, though less blatantly so and therefore less easily captured with data. The seemingly optimistic perspective of Myanmar as a context of household harmony and gender equality does stand in stark contrast with other well documented gender discrepancies in the country such as the gender wage gap, glass ceilings, women's absence in governance, and high rates of gender-based-violence (Gender Equality Network, 2015). Work on a draft of the "Prevention of Violence Against Women Law" started in 2013, yet at the time of writing has still not been passed. The rarity of divorce and pressure from the community to avoid divorce makes it difficult for partners to exit an ill-functioning relationship. The Burmese word for household, literally translated, is "house-prison".

Third, there is a clear mismatch between the customary laws and social norms that emphasize jointness of property rights and the statutory system put in place which allows only one person to be the documented owner of property. If not specifically addressed, a continued formalization of government services may increasingly provide more overt power to the individual rather than the household in its entirety. Providing agricultural loans based on land certificates and insisting the applicant has his/her name on a land certificate is a direct example of how the formal system excludes household members to direct access. As the country increases its economic status and formalization continues, it is possible more such examples will arise. When designing and re-designing policies and laws, one must make sure not to be reliant on social norms for maintaining gender-neutrality or gender equality. 


\section{Conclusion}

Many feminist economists have argued for collecting and analyzing individual, gender-disaggregated data. Data are generally believed to provide more objective and accurate information by allowing for a quantitative assessment of whether and to what extent gender discrepancies exist as well as an identification of the drivers and impacts of these discrepancies (Doss, 2013; Doss et al., 2015). There are clear advantages to a standard set of indicators that allows cross-country comparisons and broadens the scope for analyzing and understanding men's and women's empowerment in different contexts (Alkire et al., 2013; Kieran et al., 2015). Yet, the danger of such an approach is that the data are analyzed with a one-interpretation-fits-all approach, ignoring the need for contextualization of the data. There is, unfortunately, also ample room for misinterpreting facts in the absence of an understanding of the context.

Simple measures such as reported or documented ownership may not be appropriate for comparing gender inequality across countries. The results of our quantitative and qualitative analysis underscore limitations in focusing on ownership of the house and agricultural land as indicators for women's empowerment in Myanmar and potentially more generally in Southeast Asia. These results also draw attention to the importance of contextualizing what at the surface seems to be sheer facts. For example, when analyzing documented landownership, one would conclude that women in dual-headed households rarely own any land and use it as indicator for women's disempowerment in rural Myanmar. Indeed, in most cases the man in the household is, by default, registered as the household head, and therefore his name is also added to the ownership document of the house or farmland. Yet, in practice this does not warrant a husband to sell or buy land without the consent of his wife. Moreover, female spouses will inherit the properties of their husbands regardless of whether only his name or both names are on the documents.

Our findings also raise a more general concern about the potential for an excessively narrow focus on the 'individual', in line with arguments also made by Doss and Quisumbing (In press). It is widely accepted that household welfare does not equal individual welfare, and in response economists have focused on who owns what, who decides what, and measuring outcomes for different individuals in the household. It is easily forgotten or ignored that there are contexts where "households are organized along more corporate lines, where a powerful ideology of 'togetherness' bind the activities and resources of the family together under the control of the male head" (Kabeer, 1999, p. 460)

In doing so, feminist economists, policy makers and practitioners may at best overlook the potential for synergies within households, and at worst risk damaging intra-household understanding and 
collaboration. Ignoring that a household consists of different individuals is clearly problematic yet viewing a household as a mere collection of individuals may be equally problematic. Households could in essence obtain their strength from being a coherent well-functioning unit, rather than from being a collection of individuals who may eat and live together.

Looking at the future though, we should anticipate a possible change in social norms, and to which extent the current system of land registration may become an active deterrent of gender equality. It will be key for the statutory laws to also recognize that the naming on house and land certificates may reference households rather than individuals and that any transfer of property therefore might require consent of the spouse of the person mentioned on the certificate or even all adult household members. Moreover, joint titling or the aforementioned recognition of joint property rights may be more critical and acute for a subset of communities in the country.

It is imperative to understand gender relations in order to design more effective policies and interventions, yet so little is known about gender in Myanmar. This study is not only limited in the extent to which it can cover Myanmar's vast diversity of ethnic and religious communities but also in the specific topic being researched. Property rights are only one aspect of the many factors that affect individual wellbeing. The unique context of gender relations highlighted in this study suggests that a greater volume of sounder gender research, both qualitative and quantitative, is needed to understand the needs of men and women in Myanmar and how they can be best addressed. If interventions are ongoing or being planned in the country, the impacts of these interventions should be rigorously assessed and their results, whether positive or negative, be widely shared to quickly build up evidence to guide more efficient and beneficial interventions. For example, interventions such as behavior change communication campaigns aiming to reduce physical violence in the household have shown great promises in other countries (Roy et al., In press) and could potentially be another pathway to also improve the lives of Myanmar's women and girls as well as men and boys. Yet, evidence of their effectiveness in Myanmar is lacking. 


\section{References}

Agarwal, B. (1994). Gender and command over property: A critical gap in economic analysis and policy in South Asia. World Development, 22(10): 1455-1478.

Agarwal, B. (1997). "Bargaining" and gender relations: Within and beyond the household. Feminist Economics, 3(1): 1-51.

Allendorf, K. (2007). Do women's land rights promote empowerment and child health in Nepal? World Development, 35(11): 1975-1988.

Akter, S., Rutsaert, P., Luis, J., Htwe, N.M., San, S.S., Raharjo, B., and Pustika, A. (2017). Women's empowerment and gender equity in agriculture: A different perspective from Southeast Asia. Food Policy 69: 270-279.

Alkire, S., Meinzen-Dick, R., Peterman, A., Quisumbing, A., Seymour, G., and Vaz, A. (2013). The Women's empowerment in agriculture index. World Development, 52: 71-91.

Ambler, K., Doss, C., Kieran, C., and Passarelli, S. (In press). He says, she says: Spousal disagreement in survey measures of bargaining power. Economic Development and Cultural Change.

Boutry, M., Allaverdian, C., Mellac, M., Huard, S., San Thein, U., Myo Win, T., and Pyae Sone, K. (2017). Land tenure in rural lowland Myanmar: From historical perspectives to contemporary realities in the Dry Zone and the Delta. Of Lives and Land Myanmar research series, GRET. Yangon.

Boutry, M., Allaverdian, Myo Win, T., and Pyae Sone, K. (2018). Persistence and change in Hakha Chin land and resource tenure: A study on land dynamics in the periphery of Hakha. Of Lives and Land Myanmar research series, GRET. Yangon.

Datta, N. (2006). Joint titling - A win-win policy? Gender and property rights in urban informal settlements in Chandigarh, India. Feminist Economics, 12(1-2): 271-298.

Department of Population (2015). The 2014 Myanmar population and housing census. The Union Report. Census Report Volume 2. Ministry of Labour, Immigration and Population, Naypyitaw.

Deere, C.D., and Doss, C.R. (2006). The gender asset gap: what do we know and why does it matter? Feminist Economics, 12(1-2): 1-50.

Deininger, K., Goyal, A., and Nagarajan, H. (2010). Inheritance law reform and women's access to capital. Policy Research Working Paper, 5338. The World Bank, Washington, D.C.

Doss, C. (2013). Intrahousehold Bargaining and Resource Allocation in Developing Countries. The World Bank Research Observer, 28: 52-78.

Doss, C., Kovarik, C., Peterman, A., Quisumbing, A., and van den Bold, M. (2015). Land ownership and control of land in Africa: myth and reality. Agricultural Economics 46: 403-434.

Doss, C., and Quisumbing, A. (2018). Gender, Household Behavior, and Rural Development. IFPRI Discussion Paper 01772. IFPRI, Washington, D.C.

Doss, C., and Quisumbing, A. (In press). Understanding rural household behavior: Beyond Boserup and Becker. Agricultural Economics, 1-12. 
Gender Equality Network (2015). Raising the curtain. Cultural Norms, Social practices and Gender Equality in Myanmar. The Gender Equality Network, Yangon.

Hanmer, L, and Klugman, L. (2016). Exploring Women's Agency and Empowerment in Developing Countries: Where do we stand? Feminist Economics, 22(1): 237-263.

Kabeer, N. (1999). Resources, Agency, Achievements: Reflections on the Measurement of Women's Empowerment. Development and Change, 30: 435-464.

Khaing, M. M. (1984). The World of Burmese Women. Zed Books, London. 198pp.

Kieran, C., Sproule, K., Doss, C., Quisumbing, A., and Kim, S.M. (2015). Examining gender inequalities in land rights indicators in Asia. Agricultural Economics, 46: 119-138.

Kieran, C., Sproule, K., Quisumbing, A., and Doss, C.R. (2017). Gender Gaps in Landownership across and within Households in Four Asian Countries. Land Economics, 93(2): 342-370.

Lambrecht, I.B. (2016). "As a Husband I Will Love, Lead, and Provide." Gendered Access to Land in Ghana. World Development, 88: 188-200.

Lastarria-Cornhiel, S. (1997). Impact of privatization on gender and property rights in Africa. World Development, 25(8): 1317-1333.

Maung, M. (1963). Law and Custom in Burma and the Burmese Family. Martinus Nijhoff, The Hague.

Meurs, M., and Ismaylov, R. (2019). Improving Assessments of Gender Bargaining Power: A Case Study from Bangladesh. Feminist Economics, 26(1): 90-118.

Mishra, K., and Sam, A.G. (2016). Does women's land ownership promote their empowerment? Empirical evidence from Nepal. World Development, 78: 360-371.

Murdock, G.P. (1967). Ethnographic atlas. University of Pittsburgh Press, Pittsburgh. 128 p,

Pearse, R., and Connell, R. (2016). Gender norms and the economy: Insights from social research. Feminist Economics, 22(1): 30-53.

Quisumbing, A.R., Estudillo, J.P., and Otsuka, K. (2004). Land and schooling: Transferring wealth across generations. The Johns Hopkins University Press, Maryland.

Quisumbing, A.R., Meinzen-Dick, R., Raney, T.I., Croppenstedt, A., Behrman, J.A., and Peterman, A. (2014). Closing the Knowledge Gap on Gender in Agriculture. In: Gender in Agriculture. Quisumbing, A.R., Meinzen-Dick, R., Raney, T.L., Croppenstedt, A., Behrman, J.A., and Peterman, A. (Eds.). Springer, Dordrecht. Pp. 3-27.

Quisumbing, A.R., and Otsuka, K. (2001). Land inheritance and schooling in matrilineal societies: Evidence from Sumatra. World Development, 29(12): 2093-110.

Rao, N. (2006). Land rights, gender equality and household food security: Exploring the conceptual links in the case of India. Food Policy, 31: 180-193.

Rao, N. (2017). Assets, agency and legitimacy: Towards a relational understanding of gender equality policy and practice. World Development, 95: 43-54. 
Roy, S., Hidrobo, H., Hoddinott, J. and Ahmed, A. (In press). Transfers, Behavior Change Communication, and Intimate Partner Violence: Post-Program Evidence from Rural Bangladesh." The Review of Economics and Statistics.

Than, T. (2014). Women in modern Burma. Routledge, New York. 177pp.

Twyman, J. Useche,P., and Deere, C.D. (2015). Gendered Perceptions of Land Ownership and Agricultural Decision-making in Ecuador: Who Are the Farm Managers? Land Economics, 91(3): 479-500.

Wiig, H. (2013). Joint titling in rural Peru: Impact on women's participation in household decisionmaking. World Development, 52: 104-119. 


\section{ALL IFPRI DISCUSSION PAPERS}

All discussion papers are available here

They can be downloaded free of charge

INTERNATIONAL FOOD POLICY RESEARCH INSTITUTE

www.ifpri.org

\section{IFPRI HEADQUARTERS}

1201 Eye Street, NW

Washington, DC 20005 USA

Tel.: +1-202-862-5600

Fax: +1-202-862-5606

Email: ifpri@cgiar.org 